\title{
The Development of Online Learning Media by Using Moodle for General Chemistry Subject
}

\author{
Asyti Febliza $^{1}$, Oktariani ${ }^{2}$ \\ ${ }^{1}$ Chemistry Education, Universitas Islam Riau, Indonesia \\ Email: asytifebliza@edu.uir.ac.id \\ ${ }^{2}$ Chemistry Education, Universitas Islam Riau, Indonesia \\ Email: oktariani@edu.uir.ac.id
}

(Received: January-2020; Reviewed: January-2020; Accepted: March-2020; Available online: March 2020; Published: April-2020)

This is an open access article distributed under the Creative Commons Attribution License CC-BY-NC-4.0 @2020 by author (https://creativecommons.org/licenses/by-nc/4.0/).

\begin{abstract}
This study aims to develop and obtain eligible online learning media by using moodle for general chemistry subjects by using moodle. In this study, flash animation and simulation were integrated as online media in moodle to attract students' motivation. The topic in this moodle was a colloidal solution. The method of this study was the research and development method by using ADDIE model. Online learning media was validated by media and chemistry material experts, then the valid media presented to the 24 chemistry education students in Universitas Islam Riau to acquire responses toward online learning media. The results showed that online learning media is eligible and can be used as online learning media in which the average number of expert assessment reached higher than $80 \%$ with valid criteria. In addition, students' responses toward online learning media by using moodle is positive in all aspects (interesting design; color, picture, and video preference; creativity and innovation; communication) with the average number of percentage more than $84 \%$ (good criteria). Overall, based on the results of online learning media by using moodle for general chemistry subject can be used as learning media to give students experience in online learning.
\end{abstract}

Keywords: Moodle; E-Learning, Media, General Chemistry; Colloidal Solution.

\section{INTRODUCTION}

Technology has shifted education from face to face interaction into The virtual environment. Online learning is a form of a virtual environment. Online learning is a process of education through an internet network or the intranet with the use of a management system for education. Many Universities in advanced countries have conducted online learning as a part of the education system. Conversely, only a few of University in Indonesia apply it. Reporting from the Ministry of Education and Culture Indonesia on 4 February 2019, Muhammad Nasir (Minister of the Education and Culture Indonesia) revealed that in the future, University in Indonesia should to conduct online learning.
Furthermore, a survey was conducted by Asosiasi Penyelenggara Jasa Internet Indonesia (APJII) cooperating with Pusat Kajian Komunikasi (Puskakom) Universitas Indonesia showed that Internet user in Indonesia reached 88,1 million in the beginning of the year 2015 (Kurnia, Santi, \& Astuti, 2017). In addition, a survey of Wearesocial declared that Internet users of Indonesia from January 2016 to January 2017 increased at about 51\% reached 132,7 million users. Besides that, based on the survey result of the Indonesia Ministry of Information cooperating with UNICEF was obtained information that 79,5\% internet and digital media users are a teenager (Kurnia et al., 2017). Meanwhile, teachers in Indonesia still use a lot of 80 's learning media and the 20th Century 
Education system which causes a significant gap between teachers and students in the school.

Faculty of education and teacher training Universitas Islam Riau is a university which educate student to be a professional teacher. It also has internet access for all academic community. However, Internet utilized has not been optimum in teaching and learning process. Even though to provide a prospective teacher who are able to compete with others, the learning process needs to be renewed leading to optimization of internet usage or online learning. Furthermore, in Faculty of Education and Teacher Training there is no independent elearning webpage to help students get experience with e-learning. Besides that, lectures have no experience and never use e-learning based on moodle in their teaching and learning process. Therefore, researchers tried to develop online learning media by using moodle as Learning Mangement System (LMS).

This study was conducted to develop and obtain eligible online learning media for basic chemistry subjects by using moodle. Moodle (Modular Object-Oriented Dynamic Learning Environment) is basically an Open Source elearning platform designed to facilitate collaboration, based on online learning approach and finding (Cahir, J., McNeill, M., Bosanquet, A., \& Trawoger, 2014; Chourishi, D., Buttan, C.K., Claurasia, A \& Soni, 2015). In this study, flash animation and simulation were integrated as online media in moodle to attract students' motivation. Febliza, A., Afdal (2019) argued that flash animation increased students' motivation, so that it would affect to students' learning outcomes. Chemistry topic was colloidal solution. Besides that, in the moodle website students enabled to interact with each other in discussion forum and followed evaluation tests with random questions. In this study, online learning media was validated by media experts, chemistry subject experts and users.

Moodle was choosen as a Learning Management System (LMS) in this study because it presents an excellent platform for resources and communication tools which has some privilage features, namely: discussion forum, file exchange, email notification, notification dashboard, progress review, searching within course, dan module page as well as optimized architecture compared with other e-learning systems (Subramanian, P., Zainuddin, N., Alatawi, S., Javabdeh, T. and Hussin, 2014).

In addition, Yildiz, Tezer, \& Uzunboylu,
(2018) proposed some benefits of moodle that make it the most popular LMS, such as: moodle is an open source platform which accessible, simple terms, users and administrators can freely run, share, and alter it to meet their particular commercial or non-commercial needs. Beside that, it is no license fee required, user friendly with simple interface (HTML 5), Easy to customize and can be accessed on any mobile device.

Media moodle can be accessed via personal computer, notebook or smartphone which connected with internet. It also can minimize smartphone abuse by students while the ongoing learning process in the classroom, as well as familiarize students to learn ICT-based to meet the digital era (Puspita Sari \& Setiawan, 2018).

Chourishi, D., Buttan, C.K., Claurasia, A \& Soni (2015) explained about types and access mechanism of moodle. After the installation of moodle, we can get an administrator account and its password. We can create courses by using this account, add users to the system, and manage other system functions. Moodle uses a role based access mechanism, and implements three major roles: administrator, teacher, and student. A user can be given any of these roles. A user can be a student in one course, and a teacher for another. A teacher can also be the system administrator. An administrator can control and create courses or assign teacher role to others or assign administrator role to any one else. When a user enrolls in a particular course then the student role will be given. Moodle provides four types of access mechanism for students to join a course. The first is the simplest method which no authentication requires and allows any user to join the course. The second is a guest user mode where the user can go through the course, but cannot participate in any activity. The third mode requires the teacher to enroll each student directly one by one in which the teacher has full control in adding or removing students. Both enrolment and expulsion are done through a simple interface that can be accessed through the participant link on the homepage. It shows a list of all valid users on the system and the list of current students. The fourth option uses an enrolment key set by the teacher and students must provide this key on their first entry to enroll them in the course. If the key is valid, the enrolment is complete, and further access does not require the key. All these operations can be done by choosing the "settings" option in moodle course page. 
Research about online learning media by using moodle has been conducted by some researchers, but the research just determine the effect of online learning for some aspects, such as: students' attitude, motivation, etc and no explaination about how to validate online learning media before it was used as learning media. However, this research was conducted to validate online learning with experts justification and users response which is not done by other reserchers. In addition, research about developing online learning media for general chemistry subject is rarely conducting by other reseachers. The results of their study proposed that online learning media by using moodle in a scchool can improve students' learning outcomes, increse students' confidence and attitude, facilitate students' collaboration and discussion between other students as well as teachers without limited time and space (Afdal, 2012; Cahir, J., McNeill, M., Bosanquet, A., \& Trawoger, 2014; Chen, P. C., Lan, T. S., Chiu, S. C., \& Lan, 2014). In addition, Sampurno, P. J., Maulidiyah, R., \& Puspitaningrum (2015) declared that online learning media by optimize such as MOODLE is appropriate learning media development to be applied in accordance with the demands of the curriculum of 2013. Furhermore, Gülch, Al-Ghorani, Quedenfeldt, \& Braun (2012) obtained result of development of e-learning tolls and methods in Digital Photogrammetry and Remote Sensing (DRPS) for non experts that the overall quality of the developed learning system showed a positive impact and high possibility to make learners from academia and non-academic sector being experts and non- experts to get the initial knowledge in DPRS in a modern and economic way.

Sari, Baedhowi, \& Indrawati (2017); Yuen, A.H.K; Cheng, M \& Chan, (2019); Gülch, Al-Ghorani, Quedenfeldt, \& Braun (2012) conducted literature review from various research and found that moodle gives positive impact to students and teachers, students satisfied in average waiting time for a response, feedback quality, material thoroughness, material clarity, website user-friendliness, cooperation diversity, and material quantity. Moodle encourages students to acquire more experiences that can improve students'learning outcomes, motivation, communication, interest, discipline, and confidence. Besides that, moodle also give positive effect to the teacher, because teacher can monitor the students better and use it as a learning medium at the same time as well as one of the ways to improve the effectiveness of learning and it also showed students satisfaction according to how much time they spent using the Moodle application, average waiting time for a response, feedback quality, material thoroughness, material clarity, website user-friendliness, cooperation diversity, and material quantity (Tee, S. S., T. S. Mariam, T. Wook, 2013; Yuen, A.H.K; Cheng, M \& Chan, 2019; Zakaria, E., 2013).

This study aims to develop and obtain eligible online learning media by using moodle for general chemistry subjects by using moodle. Expert's decisions and user responses are considered media validation. The hypothesis of this research is "Is online learning media by using media for general chemistry subject eligible.

\section{METHOD}

The subjects of this study were 24 students of the chemistry education department in Universitas Islam Riau who were respondents to obtain information about user responses. Determination of the sample using a purposive sampling technique based on certain considerations. Since this online learning media made for basic chemistry subject.

The method of this study was the research and development method by using ADDIE model (Thim Mabrey, 2006). ADDIE model consisted of 5 steps could be seen in figure 1 .

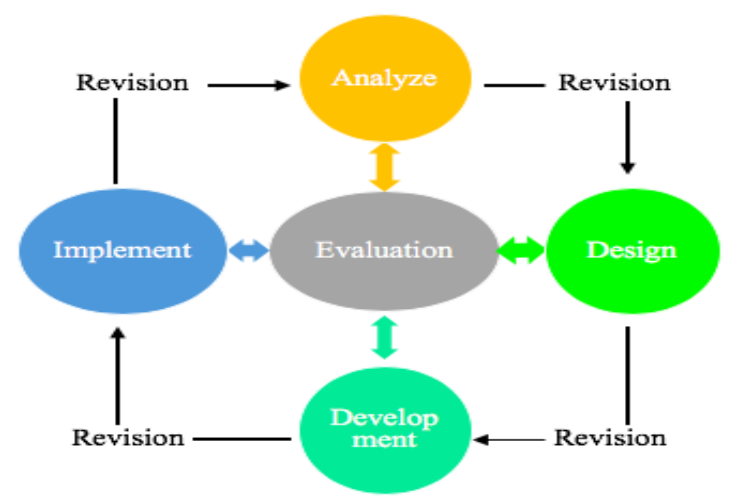

Figure 1. ADDIE Model (Thim-Mabrey, 2006)

In the first step (analyze), the researcher analyzed the current situation, colloidal solution material as well as students' and teacher's needs. Then, online learning media was designed in the second step. The media included colloidal solution material, animation, experiment simulation, and evaluation tests. Animation and experiment simulation were used available flash files from the internet, then it was modified based on lecture needs. In this step, experts executed 
validation for the content and media. Then, the researcher revised the media until experts decide the media was valid After that, in the third step online learning media was developed and implemented in the fourth step to obtain students' responses about online learning media.

Research instruments were validation sheet for expert and user response questionnaire. The validation sheet for material experts consisted of three assessment aspects, namely: competency, content and evaluation compatibility. Each indicator had five Likert level scales started from $5=$ very compatible until 1 = very incompatible (Febliza, A., Afdal, 2015). In addition, the validation sheet for media experts composed of two assessment aspects, namely: software engineering and communication. Validation sheet was given to two material exerts and two media experts. Then, the result of validation sheet calculated as an average number of two experts and interpreted into eligibility criteria showed in table 1 (Riduwan, 2012).

Table 1. Eligibility criteria

\begin{tabular}{ll}
\hline Percentage $(\boldsymbol{\%})$ & Criteria \\
\hline $80,00-100$ & Valid \\
$60,00-79,99$ & Quite valid \\
$50,00-59,99$ & less Valid \\
$0-49,99$ & Not good (changed)
\end{tabular}

Furthermore, the user response questionnaire distributes into students after online learning media was used by students. The user response questionnaire consisted of four assessment aspects, such as communicative, creativity and innovation, color, picture, and video preference as well as an interesting design. This questionnaire provides five scales of grade which average was calculated and interpreted into response criteria in table 2. During the validation process, online learning media was revised until experts judged the online learning media by using moodle was valid. Then, user responses were needed to obtain information about the media. 24 students from the chemistry education department to be a sample in this step.

Table 2. Response criteria

\begin{tabular}{cc}
\hline Percentage $(\%)$ & Criteria \\
\hline $80,00-100$ & Good \\
$60,00-79,99$ & Pretty good \\
$50,00-59,99$ & Not good \\
$0-49,99$ & Very not good (changed) \\
\hline
\end{tabular}

\section{RESULTS DAN DISCUSSION}

\section{Results}

Online learning media containing colloidal solution material can be accessed on the website of online learning www.asytifebliza. milaulas.com. Students can be accessed the website after they have an account in the registration step. They can join the website as a guest user, but they are not able to join the classroom and get material from that website. Frontpage appearance could be seen in figure 2 showing the login page, while the dashboard appearance of online learning media showed in figure 3. In addition, site administration appearance can be seen in figure 4 . 

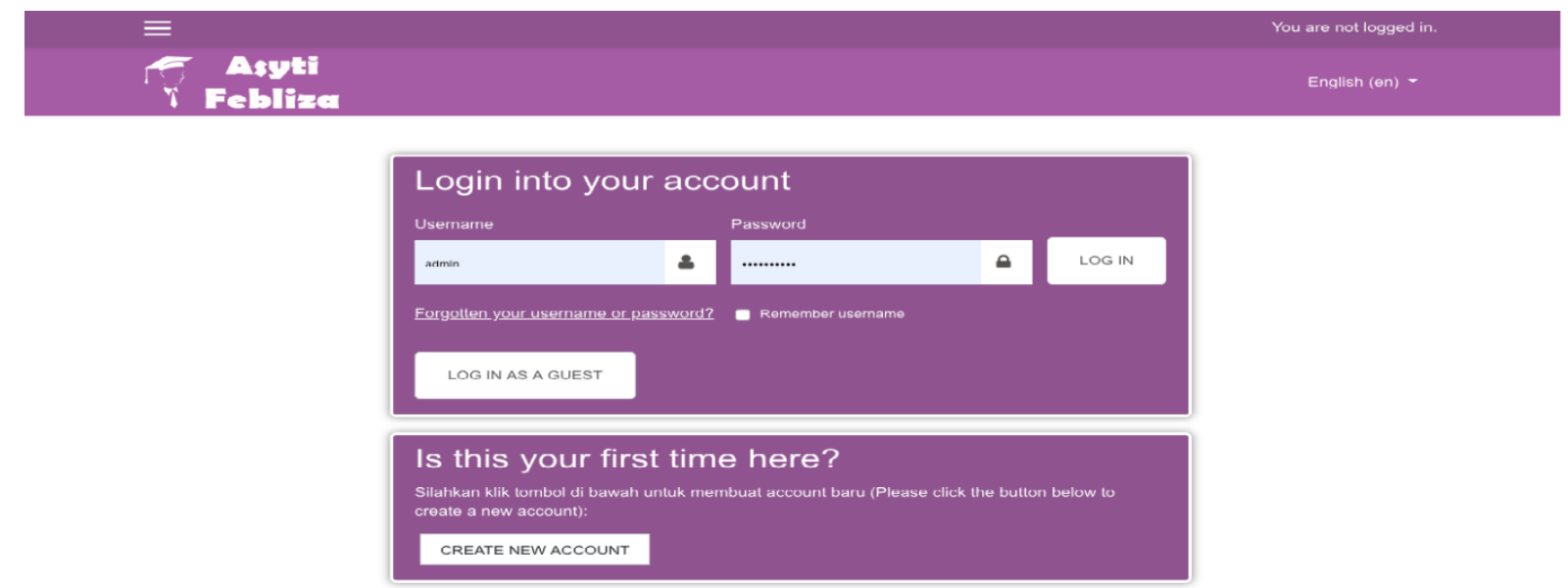

Figure 2. Screen shoot of login page appearance

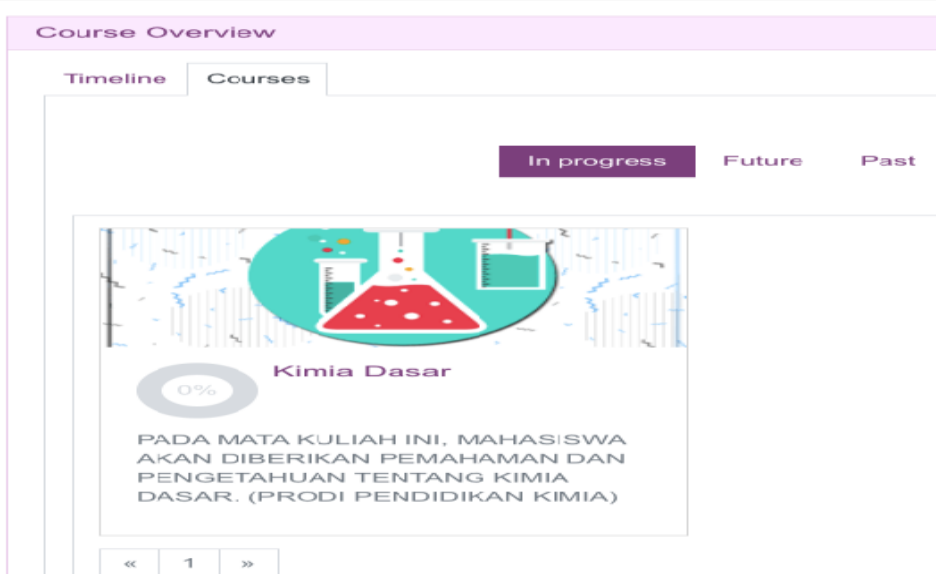

Figure 3. Screen shoot of dashboard appearance

Course administration

Course administration Users Reports

Edit settings
Turn editing on
Course completion
Unenrol me from KI24006
Filters
Gradebook setup
Backup
Restore
Import
Share
Reset

Badges Manage badges

Add a new badge

$\begin{array}{ll}\text { Question bank } & \text { Questions } \\ & \text { Categories } \\ \text { Import } \\ \text { Export } \\ \text { Purge categories }\end{array}$

Figure 4. Screen shoot of site administration appearance 
In order to acquire eligibility online learning media, assessment from experts was needed. Material experts consisted of a chemistry lecture and a chemistry teacher who assessed colloidal material in online learning media. The result of experts validated toward colloidal material showed in table 3 .

Table 3. Material experts validation result

\begin{tabular}{clcc}
\hline No & \multicolumn{1}{c}{ Aspects } & Average & Criteria \\
\hline 1 & Content and competency compatibility & $86,67 \%$ & Valid \\
& & & \\
2 & Content and material & $90,00 \%$ & Valid \\
3 & Evaluation & $83,33 \%$ & Valid \\
\hline
\end{tabular}

Based on table 3 , we can see that the average percentages of content and material reach a peak to $90 \%$, it showed that content and material aspect were clear. In general, material expert judgment were more over $80 \%$ with valid criteria. Thus, material for colloidal solution topic in online learning media could be used as eligible material.

Turning to media experts validation, online learning media was validated by two experts. The average result of online learning media by using moodle presented in table 4 .

Table 4. Media experts validation result

\begin{tabular}{clcc}
\hline No & \multicolumn{1}{c}{ Aspects } & Average & Criteria \\
\hline 1 & Software engineering & $98,00 \%$ & Valid \\
2 & Communication & $91,43 \%$ & Valid \\
\hline
\end{tabular}

Result showed in table 4 described that the average number of software engineering was the highest number at about $98 \%$. It presented that moodle was the good software engineering. Commonly, media experts validation result was higher that $91 \%$, this figure gave information that online learning media was valid.

After experts validation step, the next step was online learning media implementation to acquire users response. Users were 24 chemistry education department students. Before their join into classroom, they should to register first. After that they could join to the class and access all information in the online learning website. During the learning process, students enable to discuss each other with their friends or lecture. They were allowed to watch video, flash simulation and animation as well as evaluation question.

Furthermore, after they explored all contents and features in online learning media by using moodle, they were given response questionnaire. The result of students' response presented in figure 5 .

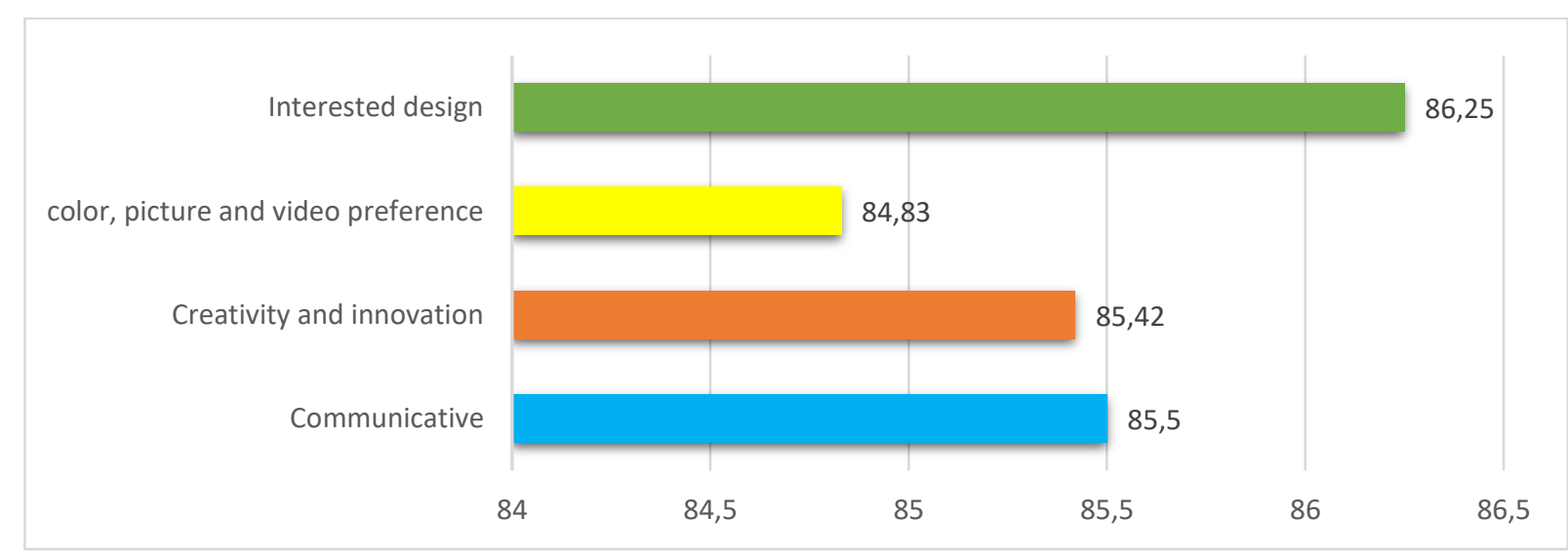

Figure 5. Students' response toward online learning media by using moodle 
The graph showed students' responses generally were good in which the average number of percentage was higher than $84 \%$ with good criteria. it indicated that students give positive responses toward online learning media by using moodle as platform. The highest number of response was interested design reached $86,25 \%$. Even though interested design became the highest number of response, the precentage of other aspects had almost the same figure with the gap at less than $2 \%$. This result is similar to Yildiz et al (2018) founded that students showed positive responses related to Moodle LMS in an educational online learning environment.

\section{Discussion}

The results of this study showed that both experts decided online learning media by using moodle for basic chemistry subject was valid. In term of basic chemistry material, it was campatible with learning objective which has been determined. It was caused, resercher can adjusted and uploded many kinds of media in online media. Furthermore, evaluation site presented randomized question, so that each students got different questions in evaluation. Beside that, student was able to check the question which has they done or not. This findings are match with research which was done by Gülch, Al-Ghorani, Quedenfeldt, \& Braun (2012). They found that moodle is easy to use and to customize and also provides dedicated built-in features for learning (Gülch, Al-Ghorani, Quedenfeldt, \& Braun, 2012).

The results of media experts validation declared that software engineering and communication aspects of moodle were valid with the average figure reached higher than $91 \%$. It was caused moodle is an open source platform which accessible, simple terms, users and administrators can freely run, share, and alter it to meet their particular commercial or noncommercial needs. Beside that, it is no license fee required, user friendly with some privilage features, namely: discussion forum, file exchange, email notification, notification dashboard, progress review, searching within course, dan module page as well as optimized architecture compared with other e-learning systems (Yildiz, Tezer, \& Uzunboylu, 2018; Subramanian, P., Zainuddin, N., Alatawi, S., Javabdeh, T. and Hussin, 2014 ).

According to students' responses results, interested design reached a peak number of all aspects at about $86,25 \%$. It was "good" criteria. In addition, three other aspects were lower slightly, although they were still in "good" criteria. This finding was match with reseach done by Tee, S. S., T. S. Mariam, T. Wook (2013); Yuen, A.H.K; Cheng, M \& Chan (2019; Zakaria, E (2013) proposed their study that students showed their satisfaction according to moodle used as online learning media for learning.

This result can be reference by others chemistry lecturer who want to develop online learning media for general chemistry subject. In addition this online learning media can be used by students to study general chemistry easily in any time and any place as well as become the first online learning media integrated flash simulation in Faculty of Education and Teacher Training Universitas islam Riau.

\section{CONCLUSION AND SUGGESTIONS}

The results showed that online learning media is eligible and can be used as online learning media in which both experts decided online learning media by using moodle for basic chemistry subject was valid. In addition, students' response toward online learning media by using moodle are positive in all aspects (interested design; color, picture and video preference; creativity and innovation; communication) with the average number of percentage stand in good criteria. So that, online learning media by using moodle for general chemistry subject can be used as learning media to give students experience in online learning. Others researcher can be developed similar media towards others subject.

We would like to thanks the Lembaga Penelitian dan Pengabdian Kepada Masyarakat (LPPM) Universitas Islam Riau which give research fund.

\section{RERERENCES}

Afdal, Z. (2012). Penerapan Pembelajaran Elearning Dengan Aplikasi Moodle Terhadap Sikap Belajar Dan Penguasaan Konsep: Studi Eksperimen Pada Mahasiswa FKIP UIR Pekanbaru-Riau. Universitas Pendidikan Indonesi.

Cahir, J., McNeill, M., Bosanquet, A., \& Trawoger, C. . (2014). Walking out the door: casualisation and implementing MOODLE. International Journal of Educational Management, 28(1), 5-14. 
Chen, P. C., Lan, T. S., Chiu, S. C., \& Lan, Y. H. (2014). A Study of Investigating the Learning Effectiveness of Applying the MOODLE E-Learning in Taiwan's Elementary School. Journal of Internet Technology, 15(7), 1191-1194.

Chourishi, D., Buttan, C.K., Claurasia, A \& Soni, A. (2015). Effective E-Learning through Moodle Moodle for E-learning. International Journal of Advance Technology \& Engineering Research (IJATER), (March 2012).

Febliza, A., Afdal, Z. (2015). Statistika Dasar Penelitian Pendidikan. Pekanbaru: Adefa Grafika.

Febliza, A \& Afdal, Z. (2019). Pemanfaatan Animasi Macromedia Flash Dalam Meningkatkan Hasil Belajar Calon Guru. Journal of Research and Education Chemistry (JREC), 1(2), 1-8.

Gülch, E., Al-Ghorani, N., Quedenfeldt, B., \& Braun, J. (2012). Evaluation and Development of E-Learning Tools and Methods in Digital Photogrammetry and Remote Sensing for Non Experts From Academia and Industry. ISPRS International Archives of the Photogrammetry, Remote Sensing and Spatial Information Sciences, XXXIXB6(September), 1-6. https://doi.org/10.5194/isprsarchivesxxxix-b6-1-2012

Kurnia, N., Santi, D., \& Astuti, I. (2017). Peta Gerakan Literasi Digital Di Indonesia: Studi Tentang Pelaku, Ragam Kegiatan, Kelompok Sasaran Dan Mitra. Informasi Kajian Ilmu Komunikasi Volume, 47(2), 149-166.

Puspita Sari, A., \& Setiawan, A. (2018). The Development of Internet-Based Economic Learning Media using Moodle Approach. International Journal of Active Learning, 3(2), 100-109. Retrieved from http://journal.unnes.ac.id/nju/index.php/ijal

Riduwan. (2012). Skala Pengukuran Variabelvariabel Penelitian. Bandung: Alfabeta.

Sampurno, P. J., Maulidiyah, R., \& Puspitaningrum, H. Z. (2015). Implementasi Kurikulum 2013: MOODLE
(Modular Object Oriented Dynamic Learning Environment) dalam Pembelajaran Fisika melalui Lembar Kerja Siswa pada Materi Optik di SMA. Jurnal Fisika Indonesia, XIX(55), 54-58.

Sari, A., Baedhowi, P., \& Indrawati, D. (2017). The Use of Learning Media with MOODLE Approach to Improve the Quality of Education: A Literature Study, 158(Ictte), 54-59. https://doi.org/10.2991/ictte17.2017 .33

Subramanian, P., Zainuddin, N., Alatawi, S., Javabdeh, T. and Hussin, A. (2014). A study of Comparison between Moodle and Blackboard based on Case Studies for better LMS. Journal of Information Systems Research and Innovation., (3-4), 26-32. https://doi.org/10.1093/oxfordjournals.rpd. a032099

Tee, S. S., T. S. Mariam, T. Wook, \& S. Z. (2013). User Testing for Moodle Application. International Journal of Software Engineering and Its Applications, 7(5), 243-252.

Thim-Mabrey, C. (2006). Sprachwandel in übersetzungsbearbeitungen zwischen 1846 und 1999. Neuphilologische Mitteilungen.

Yildiz, E. P., Tezer, M., \& Uzunboylu, H. (2018). Student opinion scale related to moodle LMS in an online learning environment: Validity and reliability study. International Journal of Interactive Mobile Technologies, 12(4), 97-108. https://doi.org/10.3991/ijim.v12i4.9205

Yuen, A.H.K; Cheng, M \& Chan, F. H. . (2019). Student satisfaction with learning management systems: A growth model of belief and use. British Journal of Educational Technology, 50(5), 25202535.

Zakaria, E., \& M. Y. D. (2013). The Role Of Technology: Moodle As A Teaching Tool In A Graduate Mathematics Education Course. Asian Journal Of Management Sciences \& Education, 2(4), 146-152. 